\title{
Lithological typing, depositional environment, and reservoir quality characterization of the "M-Field," offshore Douala Basin, Cameroon
}

\author{
G. C. Chongwain ${ }^{1}$ (1) O. O. Osinowo ${ }^{2} \cdot$ M. J. Ntamak-Nida ${ }^{3} \cdot$ T. L. Nkwanyang ${ }^{1}$
}

Received: 13 June 2018 / Accepted: 20 March 2019 / Published online: 1 April 2019

(c) The Author(s) 2019

\begin{abstract}
Sedimentary features such as channel sands and submarine fan sequences are important hydrocarbon reservoirs throughout the world and may be interpreted from bed thickness trends and log motifs. The log motifs of four well logs were employed during this study to delineate reservoir architectural depositional features and environment, determine their lithological attributes, and evaluate reservoir properties. Gamma ray log signatures were utilized to infer depositional features, discriminate litho-units, and define depositional environment; resistivity log was employed to identify reservoir zones and formation fluids, while the combined density and neutron logs aided in the estimation of reservoir porosity and lithological typing. Results of analysis show seven laterally discontinuous reservoirs: one in Well $\mathrm{X}\left(\mathrm{X}_{2}\right)$, three in Well $\mathrm{Y}\left(\mathrm{Y}_{1}, \mathrm{Y}_{2}, \mathrm{Y}_{3}\right)$, and three in Well W $\left(\mathrm{W}_{1}, \mathrm{~W}_{2}\right.$, and $\left.\mathrm{W}_{3}\right)$ with thicknesses of $6.2 \mathrm{~m}, 19.2 \mathrm{~m}, 7.6 \mathrm{~m}, 78.7 \mathrm{~m}, 100.9 \mathrm{~m}, 38.1 \mathrm{~m}$, and $41.6 \mathrm{~m}$, respectively. Reservoirs architecture reveal distributary channel sands, submarine fan lobes, and deep tidal channel-fills deposited within the deep marine mud-rich N'kapa Formation. Average porosity, water saturation, and hydrocarbon saturation values of Well $\mathrm{X}$ and Well Y reservoirs are 20.8\%,30.8\%, 69.2\%, and 40.2\%, 18.3\%, 81.7\%, respectively, indicating moderate-to-good reservoir quality. Also, the permeability values are moderate to good (74.89-12,584 md), except for $\mathrm{Y}_{3}$ and Well $\mathrm{W}$ reservoirs whose well log-derived permeabilities were unreliable due to their non-irreducible nature. Density-neutron crossplots indicate heterogeneous reservoir lithologies comprising of limestone, dolomite, and sandstones, with predominant calcite and subordinate dolomite as mineral matrix. Crossplot of water saturation and porosity revealed grain-size variation ranging from fine-grained to silty sediments with bulk volume water values suggesting Well X and Y reservoirs to be homogeneous and will produce water-free hydrocarbons, while Well W reservoirs are heterogeneous water-prone reservoirs.
\end{abstract}

Keywords Douala Basin $\cdot$ Depositional environment $\cdot$ Reservoir quality $\cdot$ Mineral matrix

\section{Introduction}

The rise in demand of energy resources and challenges associated with exploration and the development of new hydrocarbon fields, given that the easily accessible fields are already being exhausted, has begot an integrated approach to reservoir evaluation that combines geology, petrophysics, and reservoir engineering for detailed reservoir studies.

$\triangle$ G. C. Chongwain

gilmbzi@yahoo.co.uk; chongwaingilbert@gmail.com

1 Ministry of Mines, Industry and Technological Development, Yaoundé, Cameroon

2 Department of Geology, University of Ibadan, Ibadan, Nigeria

3 Department of Earth Sciences, University of Douala, Douala, Cameroon
Reservoir characterization which involves both qualitative distribution and quantitative distribution of reservoir properties, such as lithology, porosity, permeability, and fluids saturations, has been vastly used to understand reservoirs (Journel 1995), and integrating such knowledge with reservoir geometry, facies relationships, and reservoir quality is critical for exploring and exploiting these deposits effectively (Shanmugan and Moiola 1988; Johnston 2004). Quite a lot of reservoir characterizing studies have been undertaken, especially to address exploration challenges associated with complex fields, erratic stratigraphic, and facies variation including the works of Chongwain et al. (2017) who used seismic and well data to address exploration challenges associated with non-correlatable and heterogeneity of reservoirs in the Nkapa Formation of the Douala Basin. Refae et al. (2008) also applied seismic and other relevant data to characterize the puzzling Libya's Lehib field, while 
Osinowo et al. (2017) described and characterized the Eni Field, offshore, Niger delta in Nigeria, for the purposes of both improving exploration and development ventures linked to the fields.

The study area is an offshore field located within the Douala Basin with four wells of interest pseudo-named Well X, Well Y, Well Z, and Well W due to Cameroon's National Hydrocarbon Corporation (NHC) confidentiality agreement. The wells, located offshore within the PH77 Prospect (Fig. 1), penetrated the Paleocene-Eocene N'kapa Formation which was formed during a period of renewed thermal subsidence accompanied by extensive marine deposition (SPT 1994, 1995). Varying sand units will exhibit different physical characteristics whose varying environments are characterized by different log trends, geometries, and dimensions
(Allen 1970), and the reconstruction of such environments of deposition could provide an optimum framework for describing and predicting reservoir quality and distribution (Allen 1965). Information generated from well log motifs is useful for formation evaluation and pertinent at estimating hydrocarbon quantities in a reservoir (Asquith and Krygowski 2004). The ability to estimate hydrocarbon reservoir potential can be enhanced by observing their electrical resistivity and relative permeability value (Hilchie 1990; Schlumberger 1996; Uguru et al. 2002). The fast depletion of known resources and challenges encountered in exploring feasible prospects within the Douala Basin necessitated an integral study of the four wells to utilize more robust interpretation techniques that will enable better understanding of the reservoir heterogeneities of the mud-rich N'kapa Formation.
Fig. 1 Location map of the "M-Field", Douala Basin, Cameroon adopted from SPT 1995 showing the various well positions

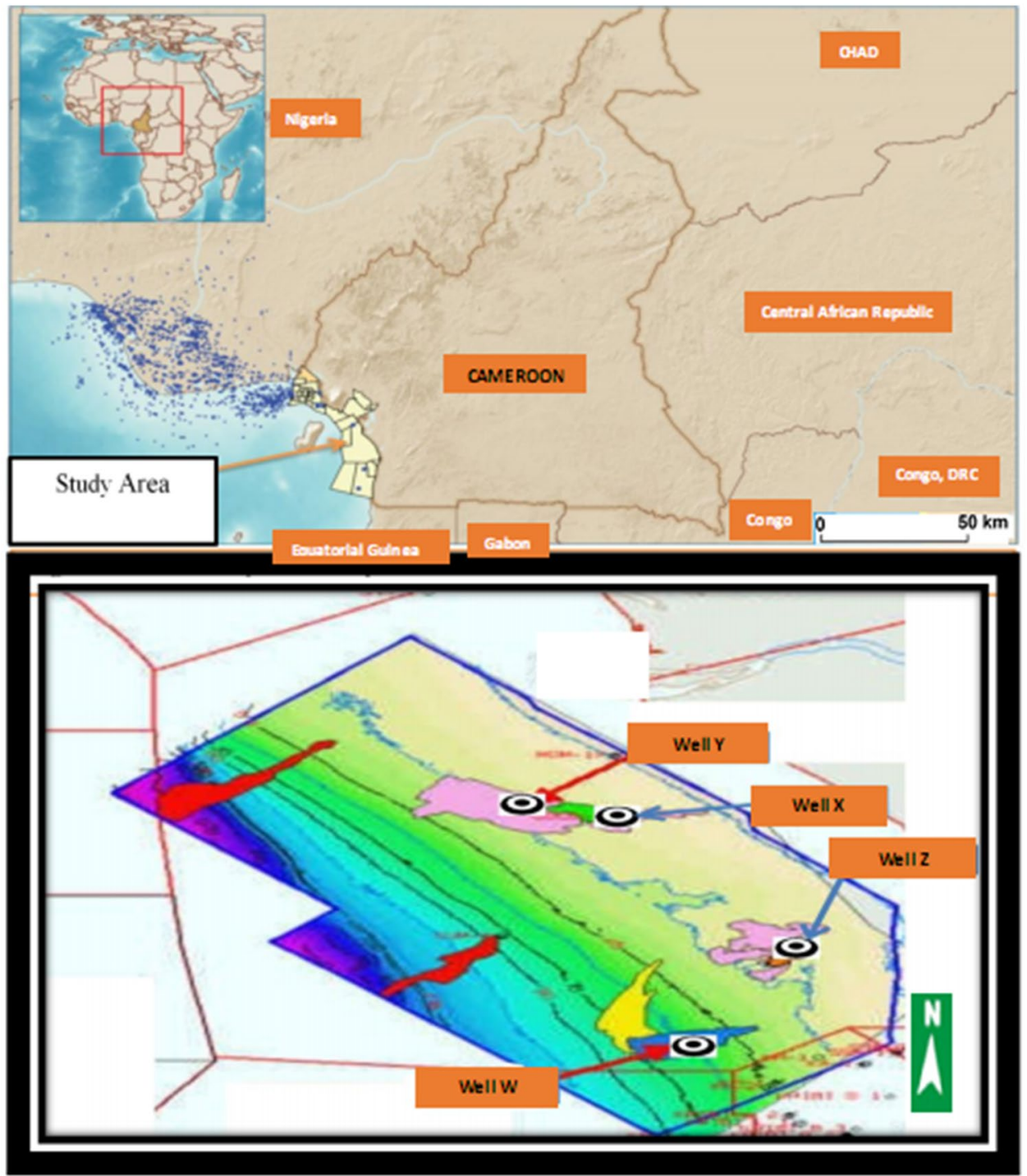




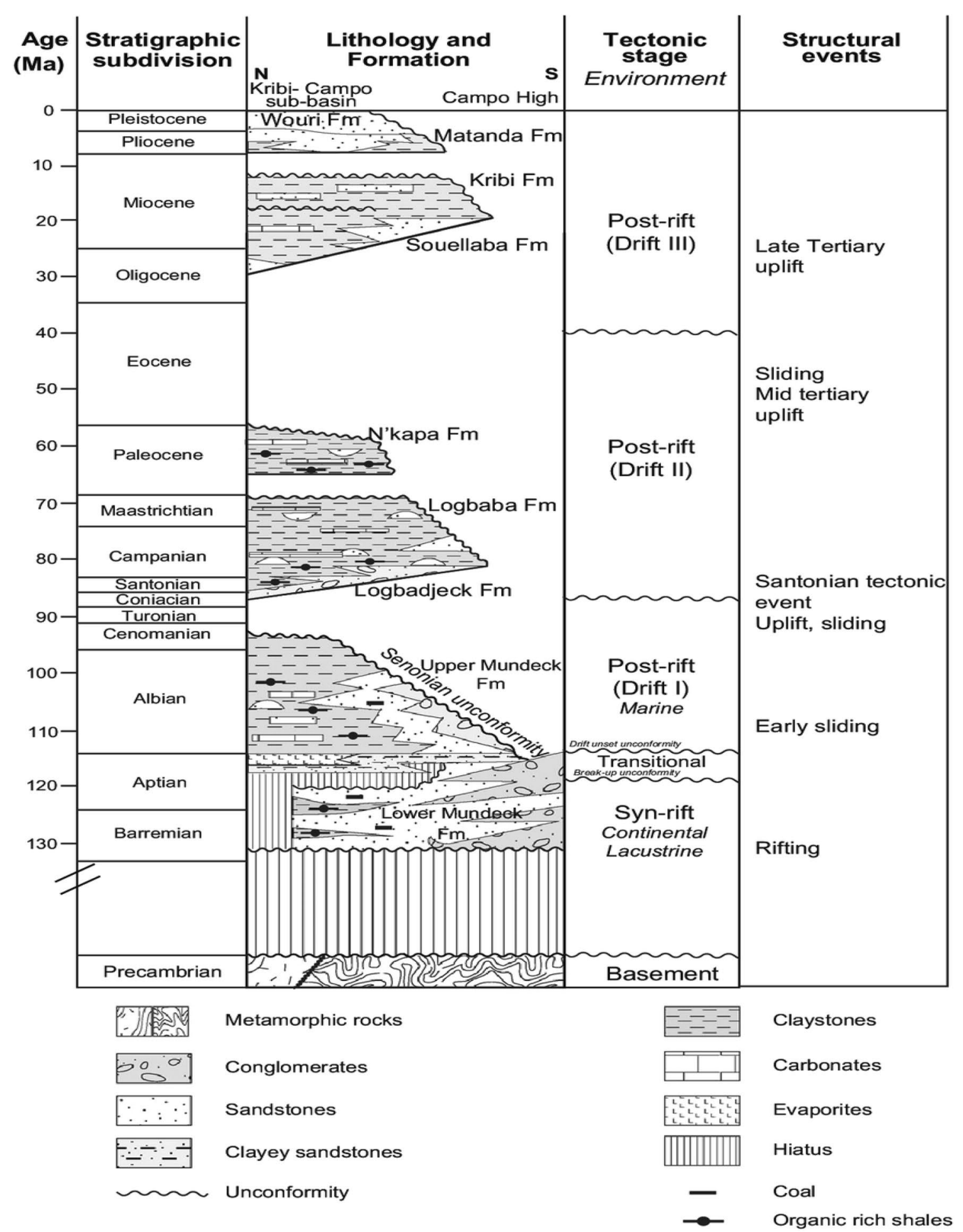

Fig. 2 Stratigraphy of the Douala Kribi Campo Basin adopted from Ntamak-Nida et al. (2010)

\section{Geological setting}

The Douala sedimentary Basin which is situated in the northern extreme of the South Atlantic constitutes a series of divergent passive margin basins along the West African coast, covering a total area of $19,000 \mathrm{~km}^{2}$ including $7000 \mathrm{~km}^{2}$ located onshore (Pauken et al. 1991). A number of geological features delimit the basin-the Cameroon Volcanic Line (CVL) to the northwest, the Pan African 
Fold Belt to the east, and the Kribi Fracture Zone to the south (Luzz-Arbouille et al. 2009). The evolution of this basin is linked to the breakup of the Gondwanaland (Burke et al. 1971) as it developed through a series of stages including the Pre-rift, Syn-rift, and Post-rifting phases, and it is characterized by various source rocks, reservoirs, seals, and traps. Deposition in this basin range from Cretaceous to Recent and the stratigraphy and sedimentology have widely been described (Brownfield and Charpentier 2006; Ntamak-Nida et al. 2010; Tamfu et al. 1995). The various lithostratigraphic units include the Mundeck, Logbadjeck, Logbaba, N'kapa, Souellaba, Kribi, Matanda, and Wouri Formations (Fig. 2), and the N'kapa Formation was deposited during the Palaeocene with no evidence of fault reactivation associated with the extension of the Atlantic during the Eustatic sea level changes that resulted in the subsidence and extensive deposition of marine sediments in neighboring basins. It lies on the Logbaba Formation and is separated from the overlying Souellaba Formation by the Eocene unconformity (SPT 1995), representing the top package of the Megasequence B (Manga 2008) and comprises mainly of silty mudstones and argillaceous sandstones which indicate muddy shelf environment. Stratigraphic trap (syn-sedimentary), mounds, and sand sheet characterize the N'kapa Formation.

\section{Materials and methods}

Four wells (W, X, Y, and Z) were subjected to reservoir quality assessment to understand the petrophysical properties, lateral extent, and the lithological heterogeneity of the sands with their environments of deposition. Wireline log data (gamma ray, natural gamma spectrometry, resistivity, density, neutron, and sonic) were used to qualitatively analyze various lithologies and their environment of deposition and to quantitatively determine the petrophysical properties of reservoir intervals with the aid of Interactive Petrophysics software. Data were made available through the National Hydrocarbon Company (NHC), Cameroon.

With the aid of the well log response character, the general trends or curve shapes of the gamma ray (GR) were used to decipher a variety of different clastic depositional systems based on the principles of Kendall (2003) and Rider (1996). GR log was employed to identify clastic reservoir units, and the deep resistivity log in combination with the GR log was used to differentiate between hydrocarbon and non-hydrocarbon bearing zones and consequently defined the zones of interest in terms of clean sands saturated with hydrocarbon (low GR and high resistivity). GR histograms were produced for each reservoir and the clustering behavior observed in order to infer the extent of cleanliness of the reservoir (Goncalves et al. 1995). Combination of resistivity (AHT90), neutron (NPHI), and density (RHOB) logs were used to discriminate the fluid type (water, oil or gas) and the characteristic "Balloon effect" usually associated with the underestimation and overestimation of gas by neutron and density $\log$, respectively, within a gas saturated reservoir served as guide.

The porous and permeable hydrocarbon saturated lithounits that possess right qualities that distinct them as hydrocarbon reservoirs were qualitatively identified using well log parameters, and the other derivative reservoir parameters such as, reservoir thickness, net-to-gross (NTG), volume of shale $\left(V_{\mathrm{sh}}\right)$ in the clastic reservoirs, effective porosity $\left(\emptyset_{\mathrm{eff}}\right)$, and hydrocarbon saturation $\left(1-S_{\mathrm{w}}\right)$ were quantitatively determine and employed to evaluate the hydrocarbon potential of the field. Given that the N'kapa Formation is Tertiary in Age (Brownfield and Charpentier 2006), the volume of shale $\left(V_{\text {sh }}\right)$ was estimated using the Larionov (1969) Tertiary Eqs. (1) and (2) (Asquith and Krygowski 2004).

Linear response $\left(V_{\text {clay }}=I_{\mathrm{GR}}\right)$ :

$V_{\mathrm{clGR}}=I_{\mathrm{GR}}=\frac{\mathrm{Gr}-\text { GrClean }}{\text { GrClay }- \text { GrClean }}$

The Larionov younger rocks nonlinear responses for Tertiary rocks

$V_{\mathrm{clGr}}=0.08336\left(2^{3.7 \times Z}-1\right)$

$\mathrm{Z}=\mathrm{V}_{\mathrm{clGr}}$

The void ratios (total and effective porosities) of the identified reservoir units were determined using the porosity logs and the density porosity model which captures the empirical relationship that relates the measured bulk density $\left(\rho_{\mathrm{b}}\right)$,

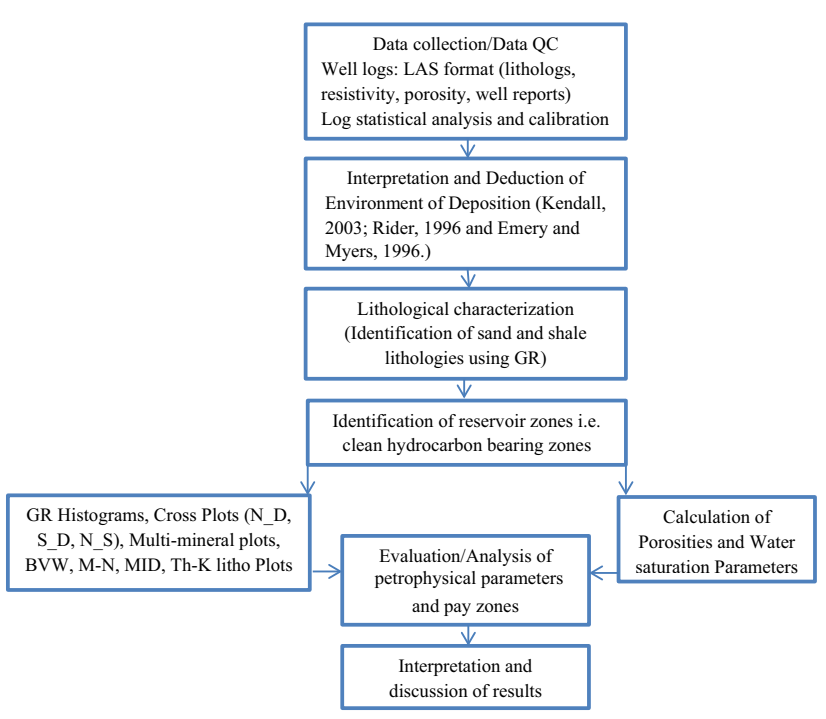

Fig. 3 Workflow adopted to characterize reservoirs, offshore SE Douala Basin, Cameroon 
(a)

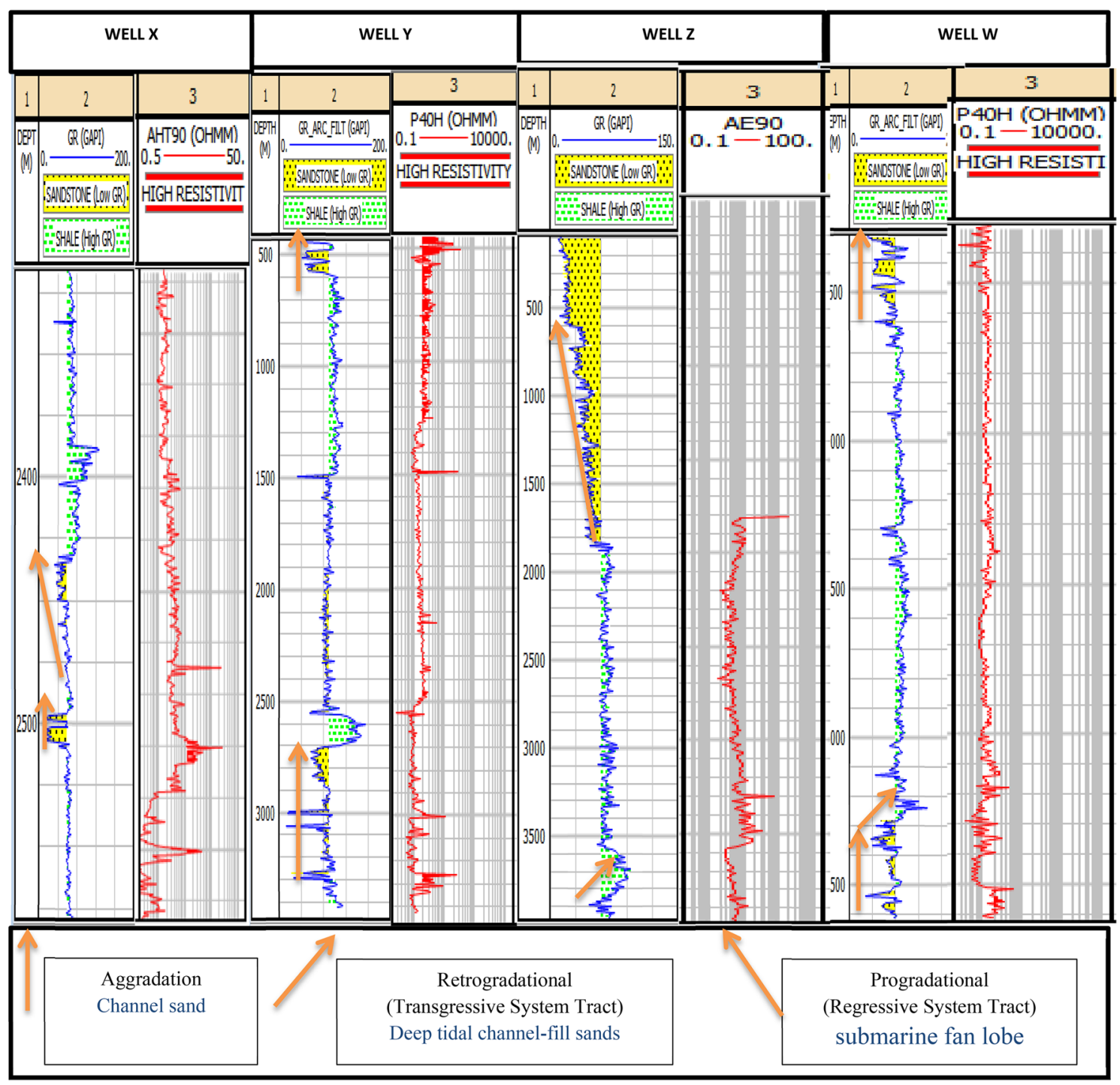

Fig. 4 a Analyzed wells depicting the various lithologies based on GR signature as well as the depositional system tracts deduced from GR response adopted from Kendall (2003), Rider (1996) and Emery

porosity $(\Phi)$, matrix $\left(\rho_{\text {ma }}\right)$, and fluid $\left(\rho_{\mathrm{f}}\right)$ densities, while integrating the clay volume effect was used to determine formation fractional porosity (Eq. 3)

$\emptyset=\frac{\left(\rho_{\mathrm{ma}}-\rho_{\mathrm{b}}-V_{\mathrm{cl}} \times\left(\rho_{\mathrm{ma}}-\rho_{\mathrm{cl}}\right)\right)}{\rho_{\mathrm{ma}}-\rho_{\mathrm{f}} \times S_{\text {xo }}-\rho_{\text {HyA }} \times\left(1-S_{\mathrm{xo}}\right)}$

where $\rho_{\mathrm{ma}}=$ matrix density; $\rho_{\mathrm{b}}=$ input bulk density log; $\rho_{\mathrm{cl}}=$ wet clay density; $\rho_{\mathrm{f}}=$ filtrate density; $\rho_{\mathrm{HyAp}}=$ apparent hydrocarbon density; $V_{\mathrm{cl}}=$ wet clay volume; and $S_{\mathrm{xo}}=$ flushed zone water saturation.

Given the importance of various fluids to the dynamic properties of reservoirs, the various fluids types were identified and their saturations quantified; the water saturation $\left(S_{\mathrm{w}}\right)$ and Myers (1996). b NW-SE Cross section through the Douala Basin illustrating stratigraphic relationships of the reservoir units

was determined for the reservoir units based on the Simandoux water saturation formula (Eq. 4) which integrated the impact of the clay volume and hydrocarbon saturation of the various reservoirs was determine using Eq. (5).

$\frac{1}{R_{\mathrm{t}}}=\frac{\emptyset^{m} \times S_{\mathrm{w}^{n}}}{a \times R_{\mathrm{w}}}+\frac{V_{\mathrm{cl}} \times S_{\mathrm{w}}}{R_{\mathrm{cl}}}$

where $R_{\mathrm{t}}=$ rock true resistivity; $R_{\mathrm{w}}=$ water resistivity; $a=$ tortuosity factor; $m=$ cementation factor; $\emptyset=$ formation porosity; $S_{\mathrm{w}}=$ effective water saturation; $V_{\mathrm{cl}}=$ wet clay volume; and $R_{\mathrm{cl}}=$ resistivity of the clay. Then using Eq. (5) below, the hydrocarbon saturation for the reservoir zone was computed.

$S_{\mathrm{h}}=1-S_{\mathrm{w}}$ or $S_{\mathrm{h}}=100-S_{\mathrm{w}}(\%)$, 


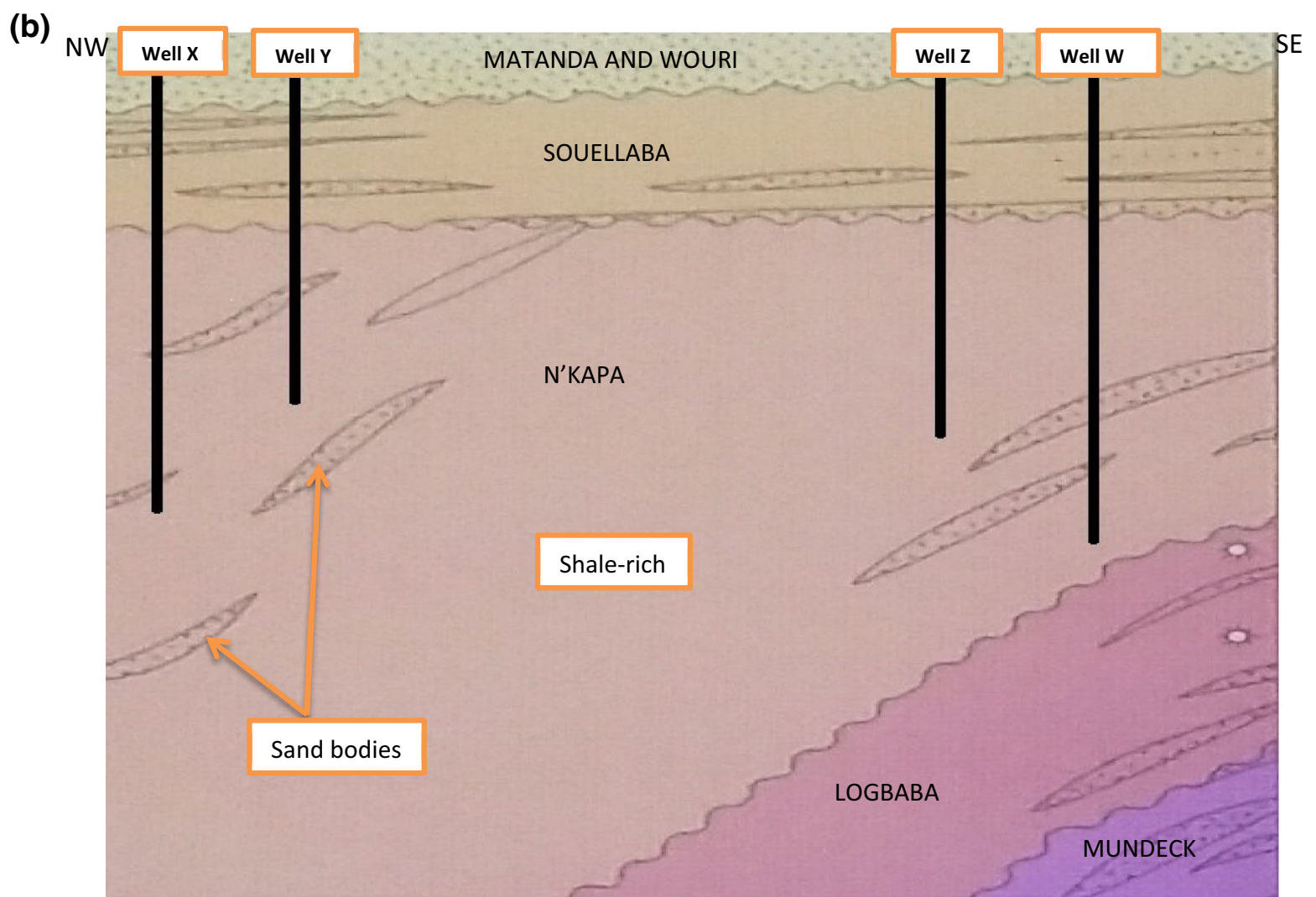

Fig. 4 (continued)

where $S_{\mathrm{h}}=$ hydrocarbon saturation; $S_{\mathrm{w}}=$ water saturation

The permeabilities of the various reservoirs to the various fluid types were established from the Wyllie and Rose (1950) relations observed in Eq. (6), and it is imperative to note that only permeability values for reservoirs at irreducible water conditions were determined as log-derived permeability formulas are only valid for estimating permeability in formations at irreducible water saturation (Schlumberger 1977).

$K=\left\lfloor 250 \times \emptyset^{3} / S_{\text {wirr }}\right\rfloor^{2} \quad$ (for oil)

where $K=$ permeability in millidarcies, $\emptyset=$ porosity, $S_{\text {wirr }}=$ irreducible water saturation.

The reservoir formation grain size of the various reservoir units was deduced by calculating the bulk volume water (BVW) which is a product of the formation water saturation $\left(S_{\mathrm{w}}\right)$ and its porosity $(\emptyset)$; and subsequently inferred grain size through the use of comparative chart described by Fertl and Vercellino (1978). In such charts, constant or very close to constant values of the bulk volume water indicate homogenous zone, at irreducible water saturation (Asquith and Krygowski 2004) that will characteristically produce water-free hydrocarbon (Morris and Biggs 1967).

$\mathrm{BVW}=S_{\mathrm{w}} \times \emptyset$
The volume of laminated clay $\left(V_{\text {lam }}\right)$, the dispersed clay $\left(V_{\text {disp }}\right)$, and the structural clay $\left(V_{\text {Struc }}\right)$ in the whole rock were calculated based on Eqs. (8) and (9) and displayed graphically in the lithological tracks of the various analyzed wells.

$V_{\text {lam }}=\left(\frac{P h i_{\mathrm{Max}}-P h i_{\mathrm{e}}}{P h i_{\mathrm{Max}}}\right)$

where $V_{\text {lam }}<V_{\text {cl }}$ then the model dispersed/laminated was used and

$V_{\text {lam }}=\left(\frac{V_{\mathrm{cl}}+P h i_{\mathrm{e}}-P h i_{\mathrm{Max}}}{1-P h i_{\mathrm{Max}}}\right), V_{\mathrm{struc}}=0: V_{\mathrm{disp}}=V_{\mathrm{cl}}-V_{\mathrm{lam}}$

Otherwise, the laminated/structural model was used and $V_{\text {disp }}=0: V_{\text {struc }}=V_{\text {cl }}-V_{\text {lam }}$.

In addition, to enable accurate reservoir lithological description relevant for reservoir management, sonic-density, density-neutron, M-N, NGS, and MID or matrix identification crossplots were further employed to determine reservoir lithology and associated constituent rock minerals. Figure 3 presents the workflow which summarizes the different activity steps embarked upon to characterize M-Field, Douala Sub-Basin, Cameroon. 


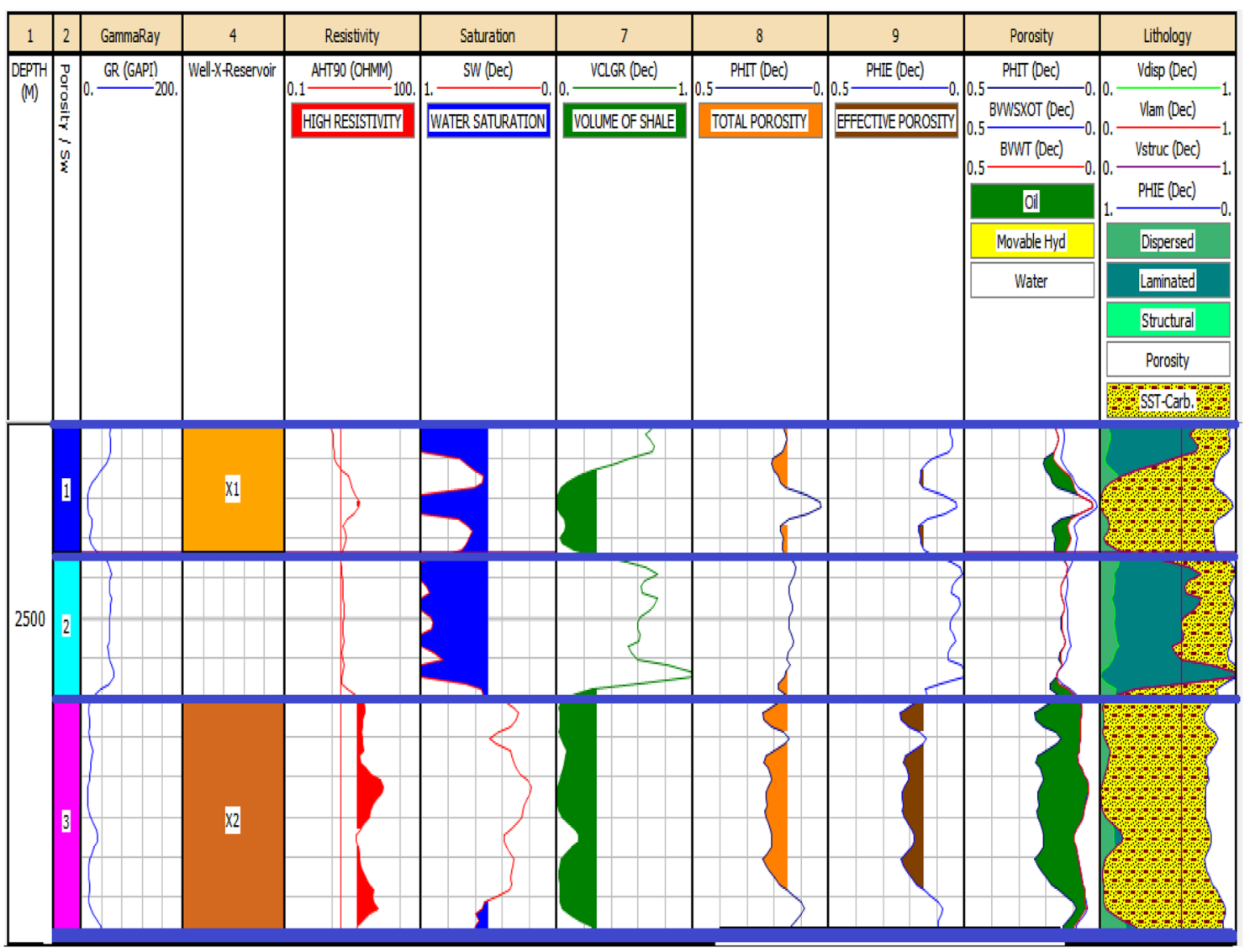

Fig. 5 Well $X$ reservoirs $\left(X_{1}\right.$ and $\left.X_{2}\right)$ with estimated water saturation volume of shale, porosities and fluid types present

\section{Results and discussion}

\section{Depositional environments}

Three major gamma ray log trends or curve shapes were observed in the studied wells including serrated (a), bell (b), and funnel (c) shapes (Fig. 4a). These varied GR shapes depict different lithological properties as the GR log tracks the upward and downward changes in the clay mineral content, and the environments of deposition of the reservoirs were predicted using the GR log motifs according to Kendall (2003). These reservoirs were interpreted as channel sands, submarine fan lobe sands, and deep tidal channel-fill, respectively (Fig. 4a).

\section{Channel sands}

The sands exhibit blocky and fining upward signatures with aggradational depositional patterns. These blocky GR signatures of the sands are usually associated with fine-grained sands of good reservoir quality due to low shale content as a result of high energy conditions leading to clean porous sands. The blocky or boxcar-shaped signature can be linked to channel sands deposited within the deep submarine fan distributary channels developed at the distal part of turbiditic successions occurring within the N'kapa Formation (Selley 1985). Such sand bodies are characteristic of the Douala Basin and often occur as pockets within the thick shaly N'kapa Formation (Fig. 4b).

\section{Submarine fan lobes}

The submarine fan lobe sands are exhibited by a funnel shape GR log trend with an upward decreasing GR pattern. This trend reflects a change from shale-rich into sand-rich lithology and upward increase in depositional energy with swallowing upward and coarsening, and probably reflects an increase in sand content of sand bodies or gradual change from clastic to carbonate deposition (Kendall 2003). The grain size of such lobes usually vary from coarse to fine, and in this study, they might have developed at or near the mouth of submarine fan channels (SPT 1995; Mutti and Ricci 1972). 


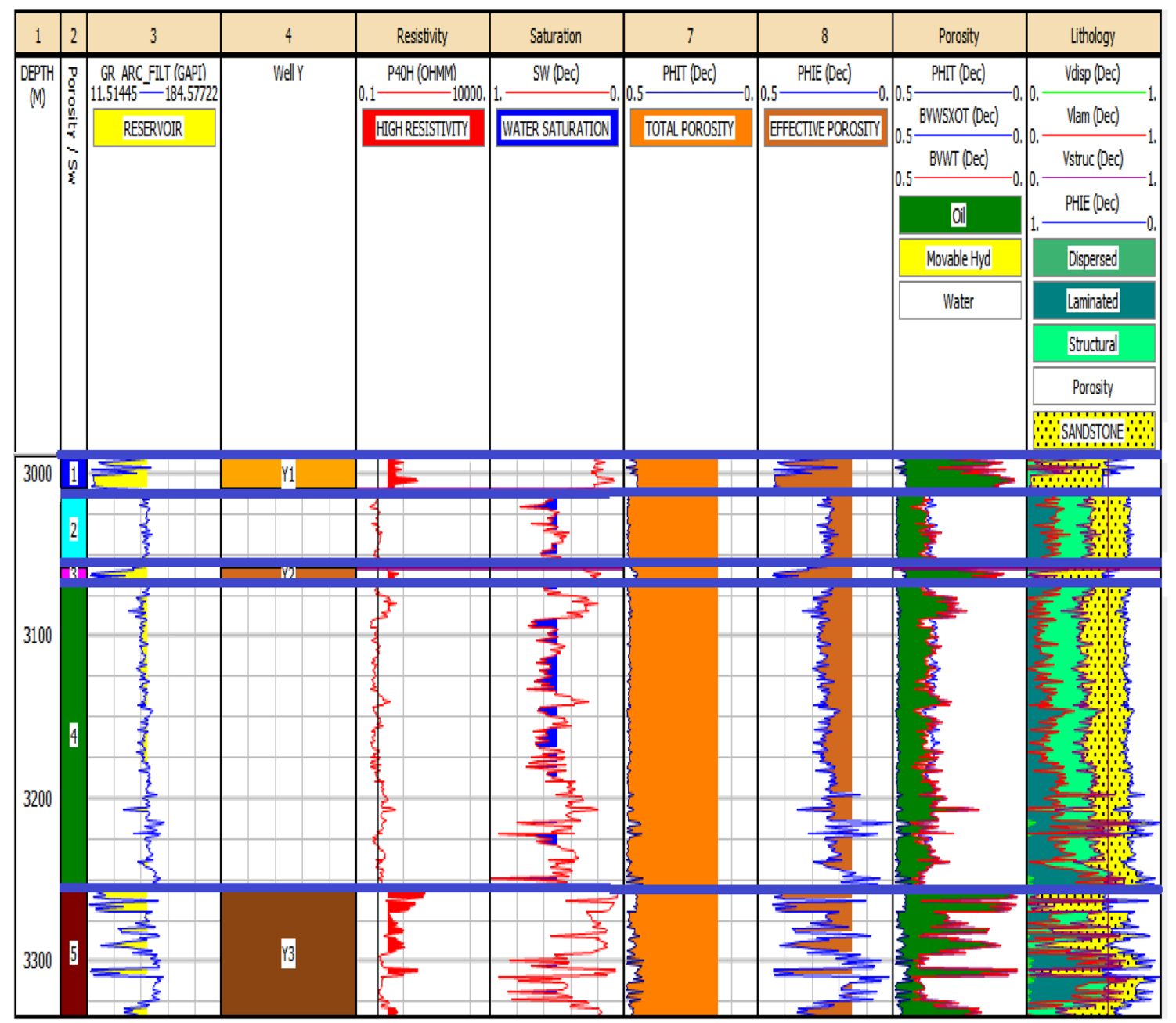

Fig. 6 Well $\mathrm{Y}$ reservoirs $\left(\mathrm{Y}_{1}, \mathrm{Y}_{2}\right.$ and $\left.\mathrm{Y}_{3}\right)$ with estimated water saturation volume of shale, porosities and fluid types present

\section{Deep tidal channel-fill}

The deep tidal channel-fill sands show bell shape motifs with a gradual upward increase with thick intercalations of shales depicting basinal directional flows of the tidal currents; depositing sands; and mud/shales, respectively. Due to the reworking by the tide, the motifs are serrated and some of the portions showed coarsening upward motif. Tidal reservoirs are usually moderate in quality but may be poorer than other shallow marine reservoirs due to the presence of numerous mud laminae resulting from drowned channel deposits. They are usually deposited by higher energy currents and are moderately to well sorted and typically less subjected to bioturbation which can be very intense in (for example) bar sands, where sedimentation rates may be lower (Shanmugam et al. 2000).

\section{Reservoir formation evaluation}

In Well $\mathrm{X}$, two sand bodies were identified including $\mathrm{X}_{1}$ and $\mathrm{X}_{2}$ with thicknesses of $3.2 \mathrm{~m}$ and $6.2 \mathrm{~m}$, respectively (Fig. 5), while for Well Y, three sand bodies were delineated including $\mathrm{Y}_{1}, \mathrm{Y}_{2}$, and $\mathrm{Y}_{3}$ with thicknesses of $15.09 \mathrm{~m}$, $6.38 \mathrm{~m}$, and $37.75 \mathrm{~m}$ respectively (Fig. 6). Well W consists of $\mathrm{W}_{1}, \mathrm{~W}_{2}$ and $\mathrm{W}_{3}$ with sand thicknesses of $100.9 \mathrm{~m}$, $38.1 \mathrm{~m}$ and $41.6 \mathrm{~m}$, respectively (Fig. 7). The results of the petrophysical evaluations show that only $\mathrm{X}_{2}$ contains hydrocarbons in Well X. Reservoirs $\mathrm{X}_{2}$ contains oil with an average hydrocarbon saturation of $0.70 \mathrm{v} / \mathrm{v}(70 \%)$. The net-to-gross for the reservoir is $76 \%$ (Table 1). Also, the average volume of clay $\left(V_{\text {clay }}\right)$ values of $0.06 \mathrm{v} / \mathrm{v}$ is below the damaging limits of $0.15 \mathrm{v} / \mathrm{v}$ (Hilchie 1978). The average porosity for the hydrocarbon bearing sand is 0.20 $\mathrm{v} / \mathrm{v}(20 \%)$, with a permeability of $74.89 \mathrm{md}$. Hence, the 


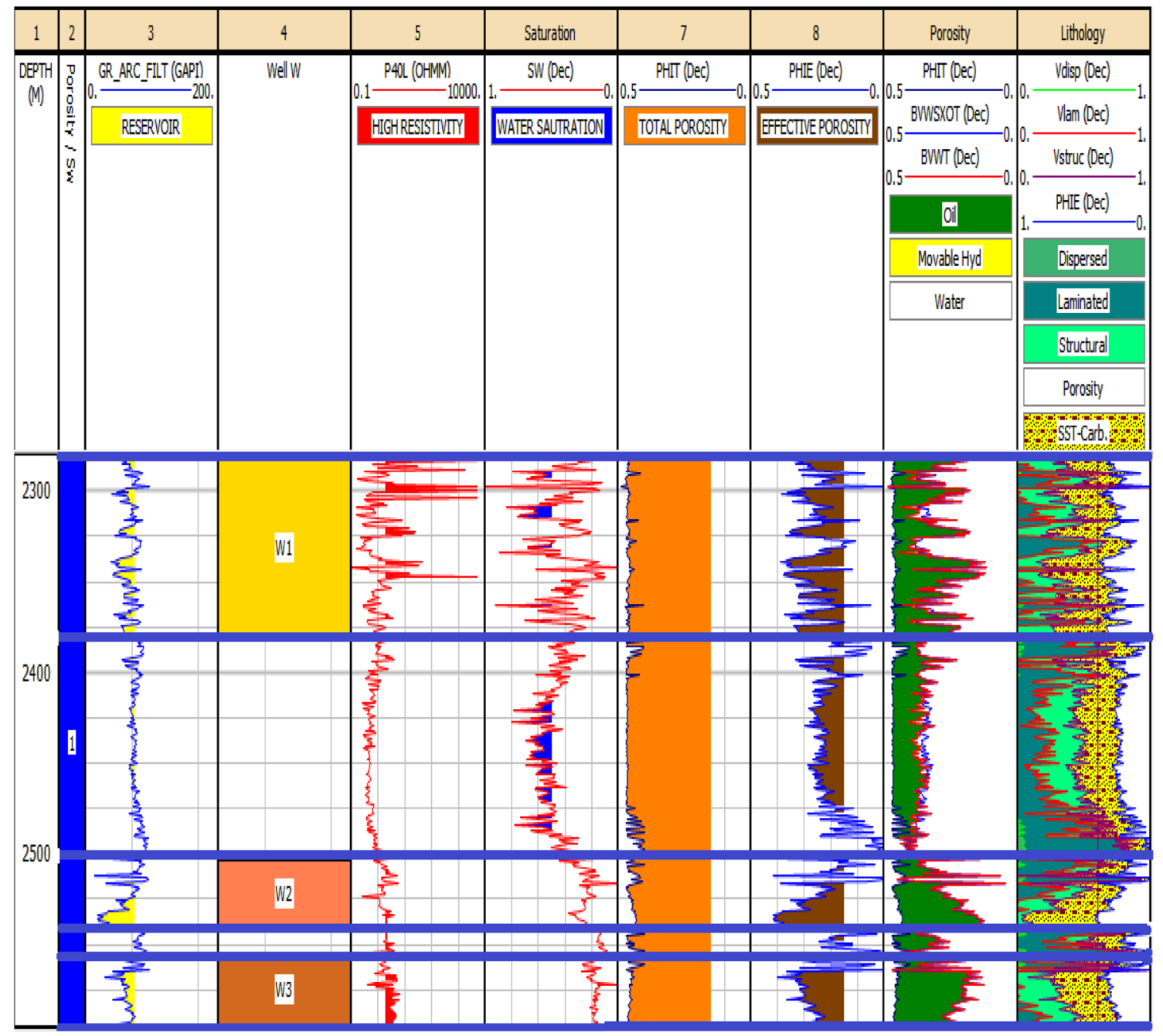

Fig. 7 Well $\mathrm{W}$ reservoirs $\left(\mathrm{W}_{1}, \mathrm{~W}_{2}\right.$ and $\left.\mathrm{W}_{3}\right)$ with estimated water saturation volume of shale, porosities and fluid types present

reservoir has good-to-excellent porosity and good permeability as well. In Well $\mathrm{Y}$, a total of three reservoirs $\left(\mathrm{Y}_{1}-\mathrm{Y}_{3}\right)$ contain hydrocarbons (Table 1). The average porosities range from 0.37 to $0.42 \mathrm{v} / \mathrm{v}(37-42 \%)$; permeability ranges from 5864 to $12,584 \mathrm{md}$ with hydrocarbon saturation range of between 0.76 and $0.83 \mathrm{v} / \mathrm{v}(77-83 \%)$. The net-gross values of $0.77-1.0$ show good sand development in the reservoirs, and they also have good-to-excellent porosity and permeability.

The good-to-excellent porosities confirm the below-limiting values of the volume of clay $(0.061-0.14 \mathrm{v} / \mathrm{v})$ in the reservoirs (Table 1), which indicates relatively low effect on reservoir quality. Finally, in Well W, three (3) reservoirs were delineated, consisting oil as the hydrocarbon type (Table 1). Average porosities for the reservoirs range from 0.34 to $0.38 \mathrm{v} / \mathrm{v}(34-38 \%)$, and water saturations range from 0.22 to 0.32 (22-32\%), which translates to hydrocarbon saturation range of between 0.68 and $0.78 \mathrm{v} / \mathrm{v}(68-78 \%)$. The reservoirs identified from petrophysical evaluation are discontinuous and non-correlatable across the entire wells and are probably thin stratigraphic carbonate-prone sandy beds pinch-outs that were deposited either as channel sands or as short turbiditic events characterizing the N'kapa Formation. The reservoirs indicate average porosities, hydrocarbon 
Table 1 Average petrophysical parameters for reservoirs in wells W, X, Y and Z

\begin{tabular}{|c|c|c|c|c|c|c|c|c|c|c|c|}
\hline Reservoir & Top (m) & Base (m) & Gross (m) & Net (m) & N/G & AvPhi E(v/v) & $\mathrm{AvSw}(\mathrm{v} / \mathrm{v})$ & $\mathrm{AvVcl}(\mathrm{v} / \mathrm{v})$ & Av sh & Perm & Fluid type inferred \\
\hline \multicolumn{12}{|l|}{ Well X } \\
\hline $\mathrm{X}_{1}$ & 2495.3 & 2498.4 & 3.3 & - & - & - & - & - & - & - & \multirow[t]{2}{*}{ Oil } \\
\hline $\mathrm{X}_{2}$ & 2502.2 & 2508.5 & 6.7 & 4.7 & 0.76 & 0.20 & 0.30 & 0.06 & 0.70 & 74.89 & \\
\hline \multicolumn{12}{|l|}{ Well Y } \\
\hline $\mathrm{Y}_{1}$ & 2990.8 & 3010 & 19.2 & 15.0 & 0.78 & 0.42 & 0.17 & 0.06 & 0.83 & 12,584 & \multirow[t]{3}{*}{ Oil } \\
\hline $\mathrm{Y}_{2}$ & 3058.4 & 3066 & 7.6 & 6.3 & 0.84 & 0.40 & 0.13 & 0.09 & 0.87 & 5864 & \\
\hline $\mathrm{Y}_{3}$ & 3256.3 & 3335 & 78.7 & 37.7 & 0.48 & 0.37 & 0.24 & 0.16 & 0.76 & - & \\
\hline \multicolumn{12}{|l|}{ Well W } \\
\hline $\mathrm{W}_{1}$ & 2281 & 2381.9 & 100.9 & 58.6 & 0.58 & 0.38 & 0.32 & 0.13 & 0.68 & - & \multirow[t]{3}{*}{ Oil } \\
\hline $\mathrm{W}_{2}$ & 2502.6 & 2540.7 & 38.1 & 3.2 & 0.21 & 0.37 & 0.22 & 0.11 & 0.78 & - & \\
\hline $\mathrm{W}_{3}$ & 2554.4 & 2596 & 41.6 & 33.8 & 0.81 & 0.34 & 0.25 & 0.20 & 0.80 & - & \\
\hline \multicolumn{12}{|l|}{ Cutoffs } \\
\hline Reservoir & - & - & - & - & - & $\geq 0.15$ & $\leq 0.5$ & $\leq 0.4$ & $\geq 0.15$ & & $\geq 0.15$ \\
\hline Pay & - & - & - & - & - & $\geq 0.15$ & $\leq 0.5$ & $\leq 0.4$ & $\geq 0.15$ & & $\geq 0.15$ \\
\hline
\end{tabular}

$N / G$ net-to-gross, $A v V c l$ average volume of clay, $A v P h i E$ average effective porosity, $A v S w$ average water saturation, $A v S h$ average hydrocarbon saturation
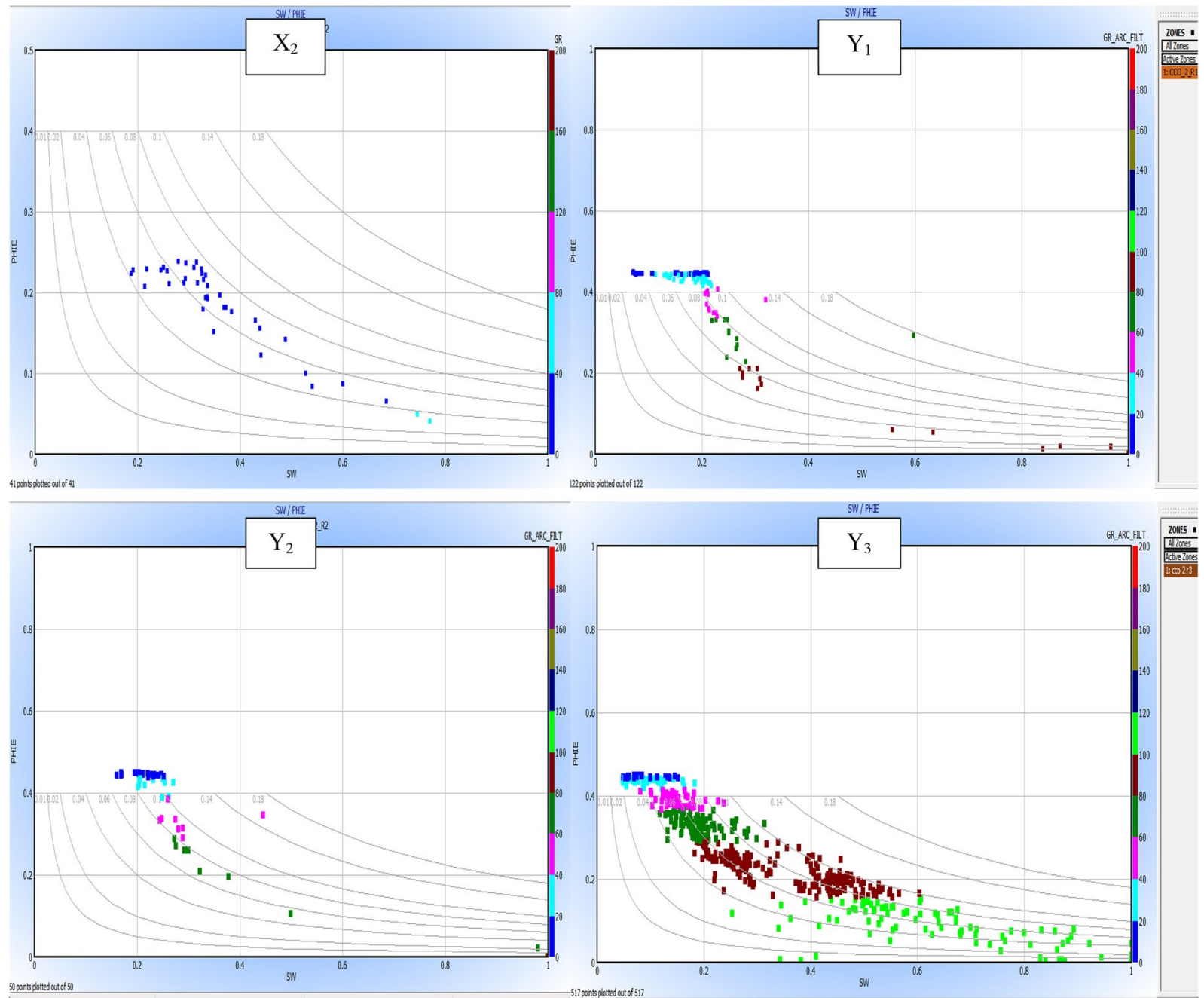

Fig. 8 Buckle plot of water saturation against porosity for reservoir's $\mathrm{X}_{2}, \mathrm{Y}_{1}, \mathrm{Y}_{2}$ and $\mathrm{Y}_{3}$ 


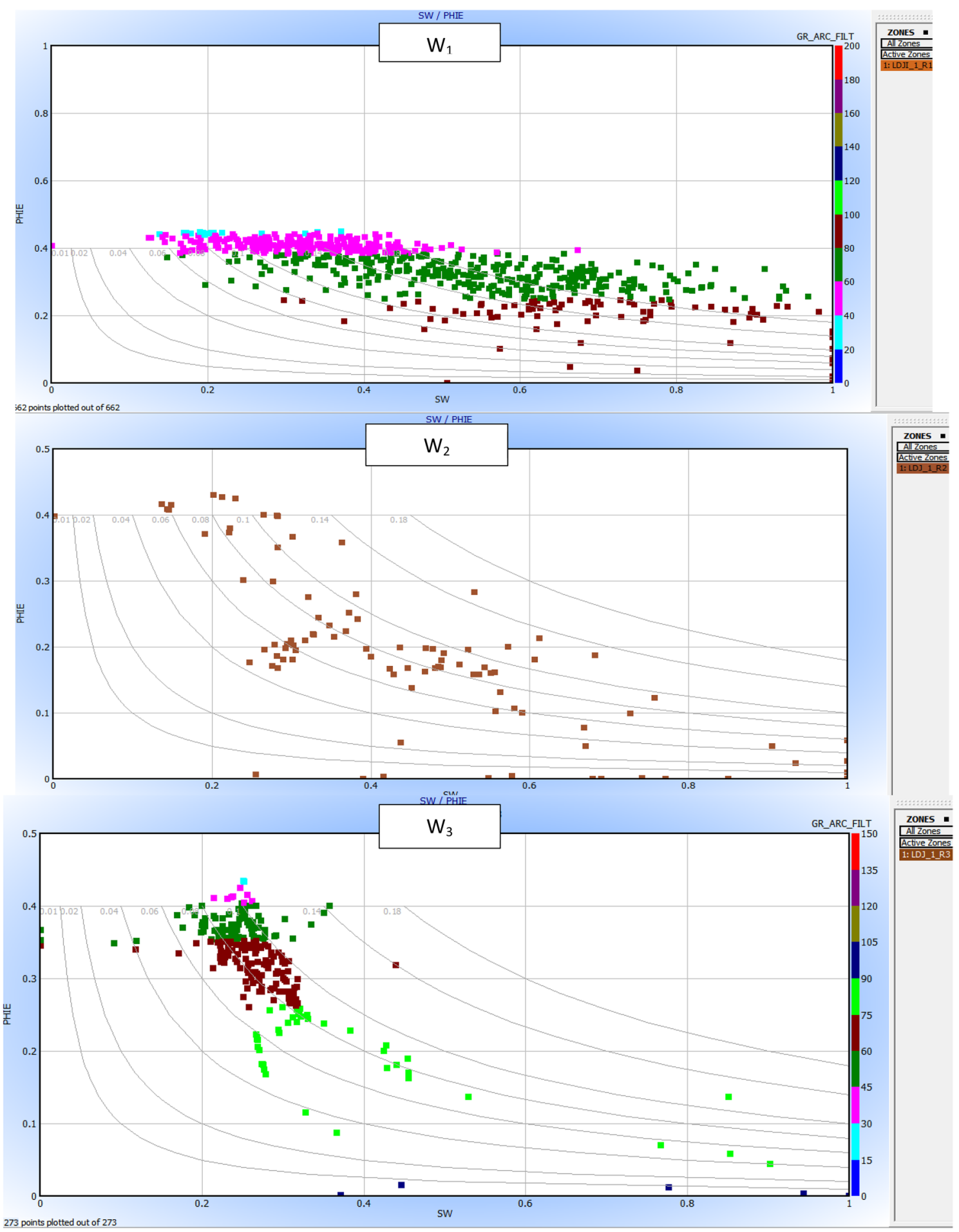

Fig. 9 Buckle plot of water saturation against porosity for reservoir's $\mathrm{W}_{1}, \mathrm{~W}_{2}$ and $\mathrm{W}_{3}$

saturation, and permeability in excess of $20 \%, 69 \%$, and 76 $\mathrm{md}$, respectively, suggesting favorable petrophysical parameters for hydrocarbon accumulation and preservation based on the classification of Rider (1986).

\section{Pay zone summary and water irreducibility}

The crossplot of water saturation ( $\mathrm{Sw}$ ) versus porosity (Ø) for reservoirs Well X, Well Y, and Well W indicate that the grain-size variation of the reservoirs ranges from 

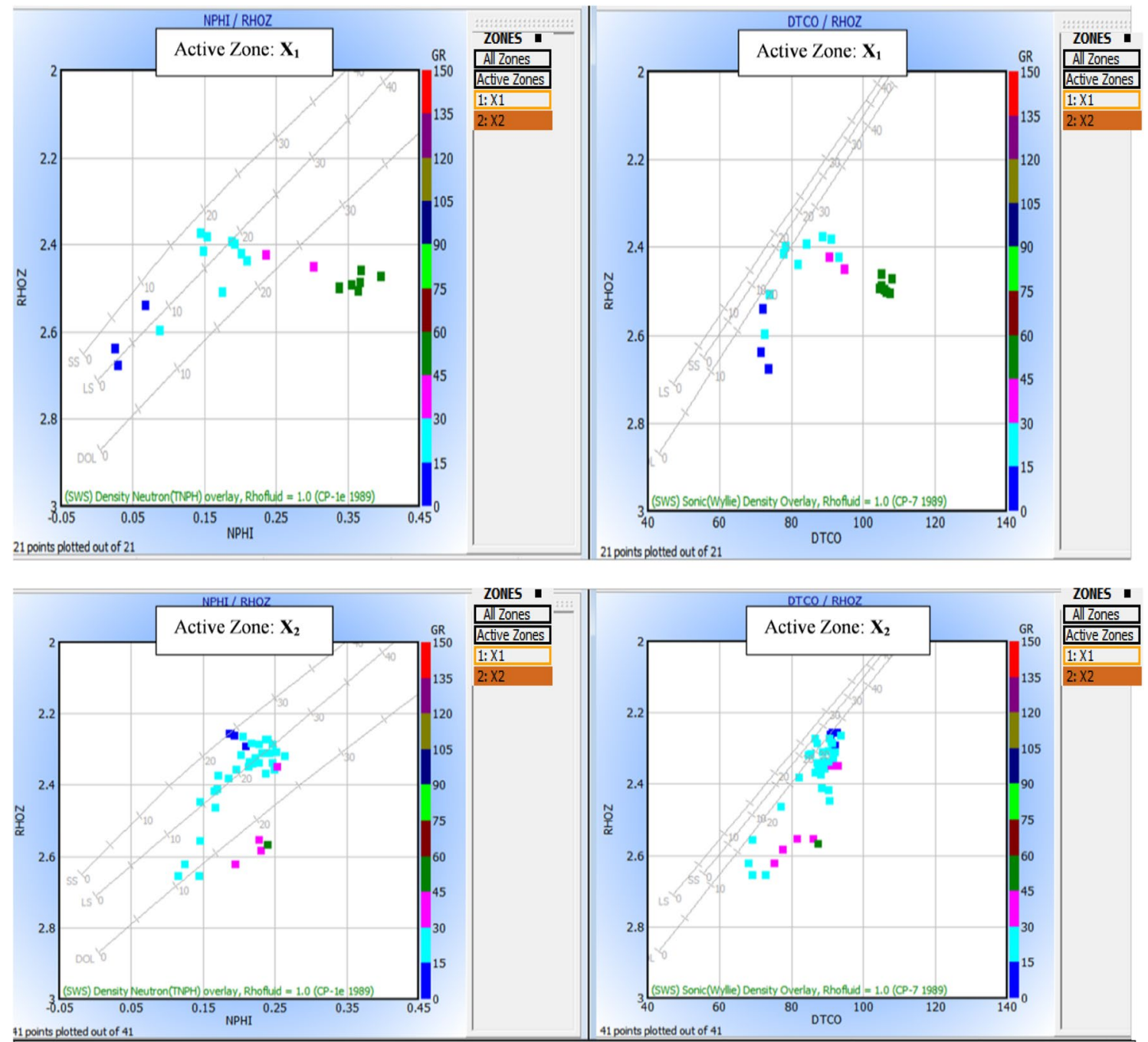

Fig. 10 Density-neutron and sonic-density for Well X reservoirs depicting points scattered across the various lithological field indicating the heterogeneous character of the reservoirs

fine-grained to silty sands based on the classification of Fertl and Vercellino (1978). Reservoir's $X_{2}, Y_{1}$, and $Y_{2}$ BVW values calculated and plotted on crossplot as established by Asquith and Gibson 1982 are constant or closed to constant and parallel to the hyperbolic lines (Fig. 8), and this indicates that the reservoirs are homogeneous and are at irreducible water saturation (Swirr) and can produce water-free hydrocarbons. When a reservoir is at Swirr, water will not move because it is held on grains by capillary pressure (Morris and Biggs 1967), and hence hydrocarbon production from $\mathrm{X}_{2}, \mathrm{Y}_{1}$ and $\mathrm{Y}_{2}$ should be water free (Asquith and Krygowski 2004). BVW plots for reservoir $Y_{3}$ and Well $\mathrm{W}$ reservoirs are scattered (Figs. 8 and 9) indicating an increase in the amount of formation water; this implies that the reservoirs are heterogeneous, and the formation has more water than it can hold by capillary pressure, and thus the reservoirs are not at irreducible water saturation $\left(S_{\text {wirr }}\right)$ and cannot produce water-free hydrocarbon during production.

\section{Lithological typing and multi-mineral characterization}

The clay/shale form of distribution pattern from the densityneutron and sonic-density crossplots (Fig. 10) for the Well X and GR histograms for Well X, Y, and W reservoirs (Fig. 11) shows that the reservoirs contain very little clay, which confirms the average $0.06,0.10$, and $0.14 \mathrm{v} / \mathrm{v}$ volume of clay estimated from petrophysical evaluation (Fig. 5; Table 1) depicting Well $\mathrm{Y}$ to host very clean reservoirs. This is possible because the high energy action that acted on the distributary channel sands must have reworked the sediments producing clean and well-sorted sands. 


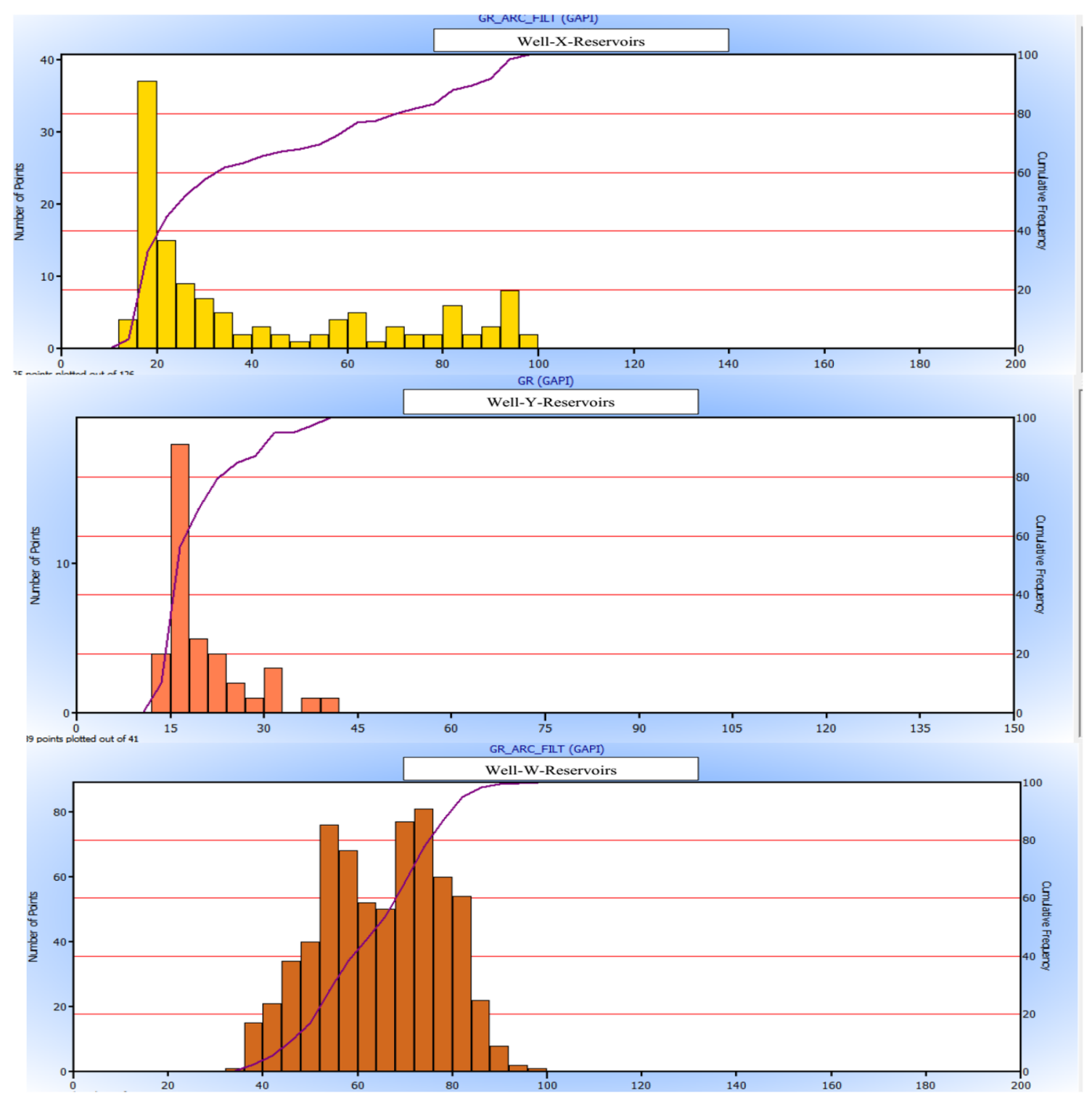

Fig. 11 GR_Histograms for Well X, Y and W reservoirs showing cleanliness of the reservoirs with respect to the GR emissions

Density-neutron and sonic-density crossplots for the Well $\mathrm{X}$ reservoirs plotted unevenly scattered within all lithological fields indicating heterogeneous lithologies, i.e., dolomite, limestone, and sandstone (Fig. 10), while the M-N lithology plots depict most of the points plotting in the dolomite and calcite fields with occurrence of secondary porosity (Figs. 12 and 13) indicating that Well $\mathrm{X}$ reservoirs are predominantly made of calcite matrix with subordinate dolomite and quartz as further confirmed by the MID plots with most of the points clustering around calcite and dolomite fields (Fig. 12), indicating calcite and dolomite as major matrix minerals constituting these rocks. The reservoirs in the study area could be described as calcareous quartz siltstones/sandstone within the N'kapa Formation due to the heterogeneous matrix which consists of fine-grained sand, limestone, and dolomite, and this probably indicates detrital carbonate, sand, and silt influx from fluvial sediments coming from the Dimbamba and Wouri Rivers or the accumulation of the remains of planktonic foraminifera forming carbonate oozes (Folk 1959). Further diagenesis led to the dissolution of the biogenic carbonate forming calcite matrix and resulting to secondary intragranular porosity prone rocks (Irwin et al. 1977; Curtis and Coleman 1986).

The Thorium-Potassium plot clustered mostly within the chlorite field (Figs. 14), indicating chlorite and montmorilorite as the dominant clay minerals. Clay minerals are usually assumed to be detrimental to sandstone reservoir quality because they can plug pore throats as they locate on grain surface in the form of films, plates and bridge and some clay minerals promote chemical 

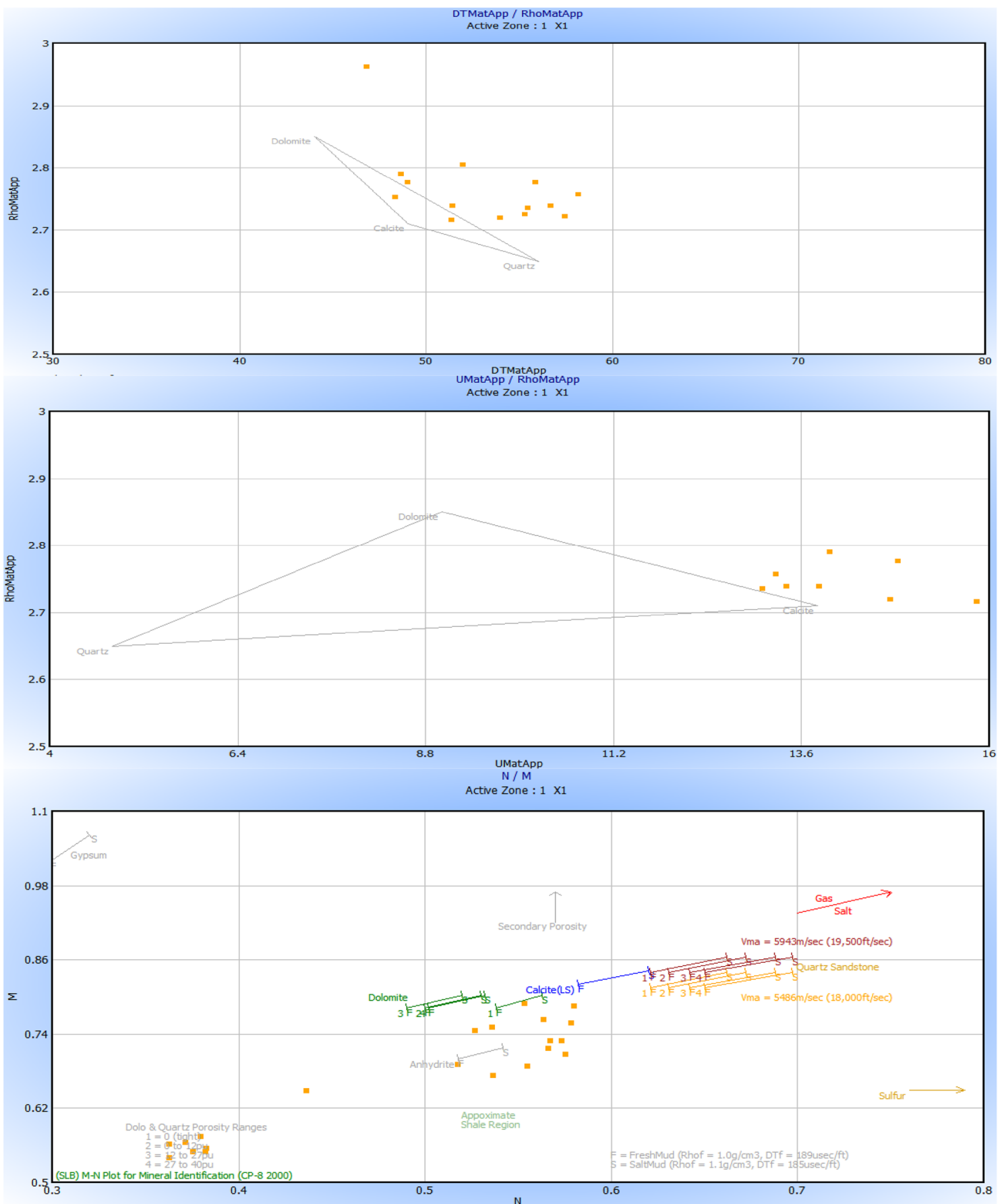

Fig. 12 MID and M-N crossplot for mineral identification for reservoir $\mathrm{X}_{1}$ (Schlumberger 1989)

compaction and also greatly accelerates the rate of porosity loss in limestone reservoir (Brown 1997). However, the existence of clay minerals does not always imply reduction in the reservoir quality, and it may be good phenomenon to indicate good reservoir quality, e.g., coats of chlorite on sand grains can preserve reservoir quality because they prevent quartz cementation (Heald and Larese 1974; Bloch et al. 2002; Taylor et al. 2004). The chlorite mineral could either be linked to detrital chlorite influx from neighboring river sediments during fast deposition and/or probably formed diagenetically during early diagenesis of feldspar and mica sediments on the seafloor. The good porosity values $(20 \%)$ observe for the Well X reservoirs indicates a minimal effect of the clay minerals on the reservoir qualities. 

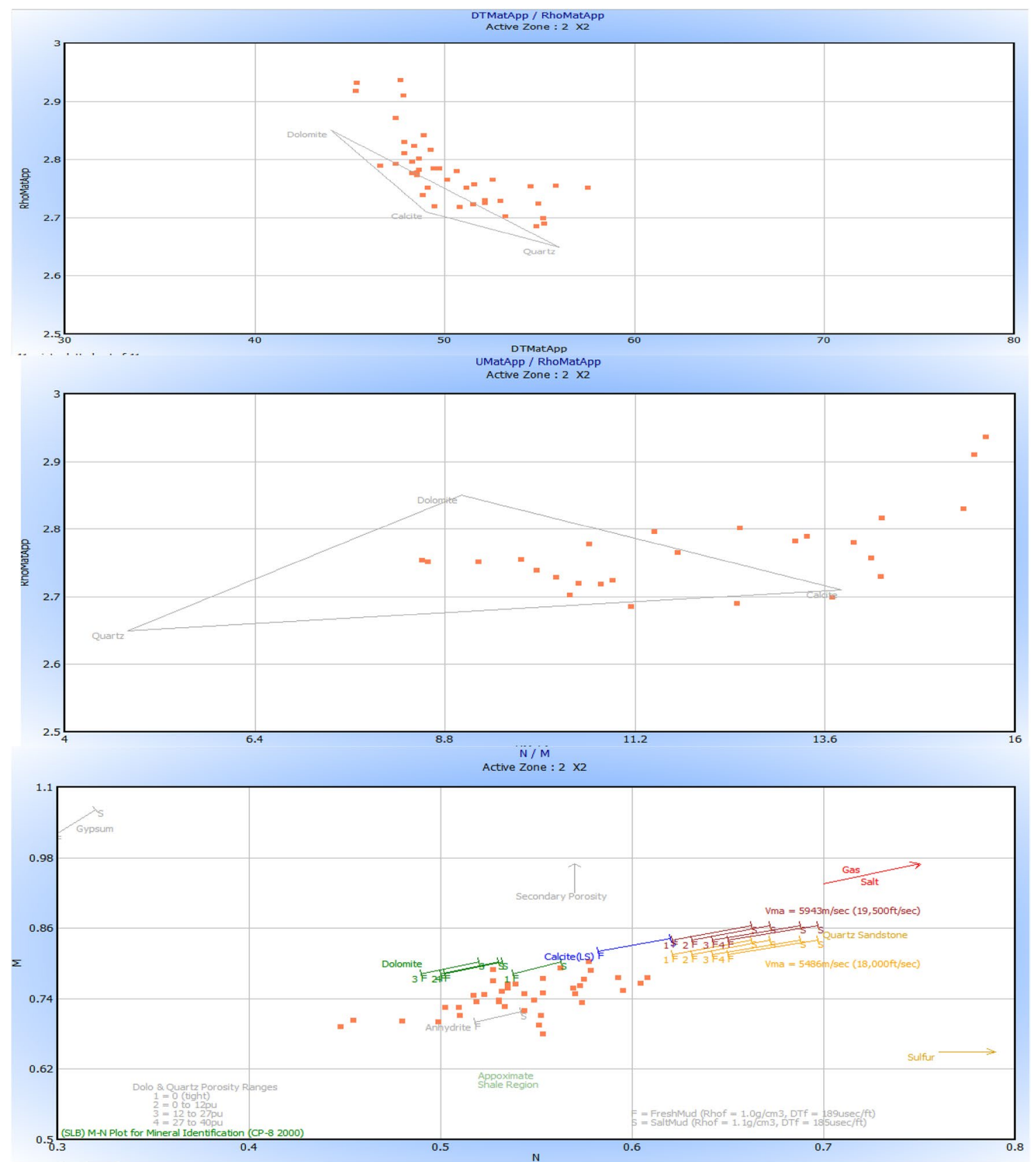

Fig. 13 MID and M-N crossplot Crossplots for mineral identification for reservoir $\mathrm{X}_{2}$ (Schlumberger 1989)

\section{Conclusion}

This study has shown that the seven (7) reservoirs $\left(X_{1}, Y_{1}\right.$, $\mathrm{Y}_{2}, \mathrm{Y}_{3}, \mathrm{~W}_{1}, \mathrm{~W}_{2}$ and $\mathrm{W}_{3}$ ) that were delineated are laterally discontinuous and non-correlatable and the interpreted log motifs indicate that the reservoirs' depositional environments span from distributary channel sand deposits, deep tidal channel-fill sands to submarine fan lobes characteristic of fan valley sediment deposited in the deep marine environment. The results from porosity to permeability confirm that $\mathrm{X}_{1}, \mathrm{Y}_{1}$ and $\mathrm{Y}_{2}$ have moderate-to-good reservoir quality. Their average water saturation and hydrocarbon saturation of $12 \%$ and $80 \%$, respectively, is an indication that Well $\mathrm{X}$ and Well $\mathrm{Y}$ sand reservoirs are charged with significant volumes of hydrocarbons predominantly oil and will produce water-free hydrocarbons. The prospects as compared to the intervals identified within the N'kapa Formation are promising with fair to significant hydrocarbon potential within the Douala Basin that can be fully developed. In terms of lithological attributes, the mineral identification crossplots 
Fig. 14 Thorium-potassium plot for Well X reservoir showing most of the points clustering in the Chlorite

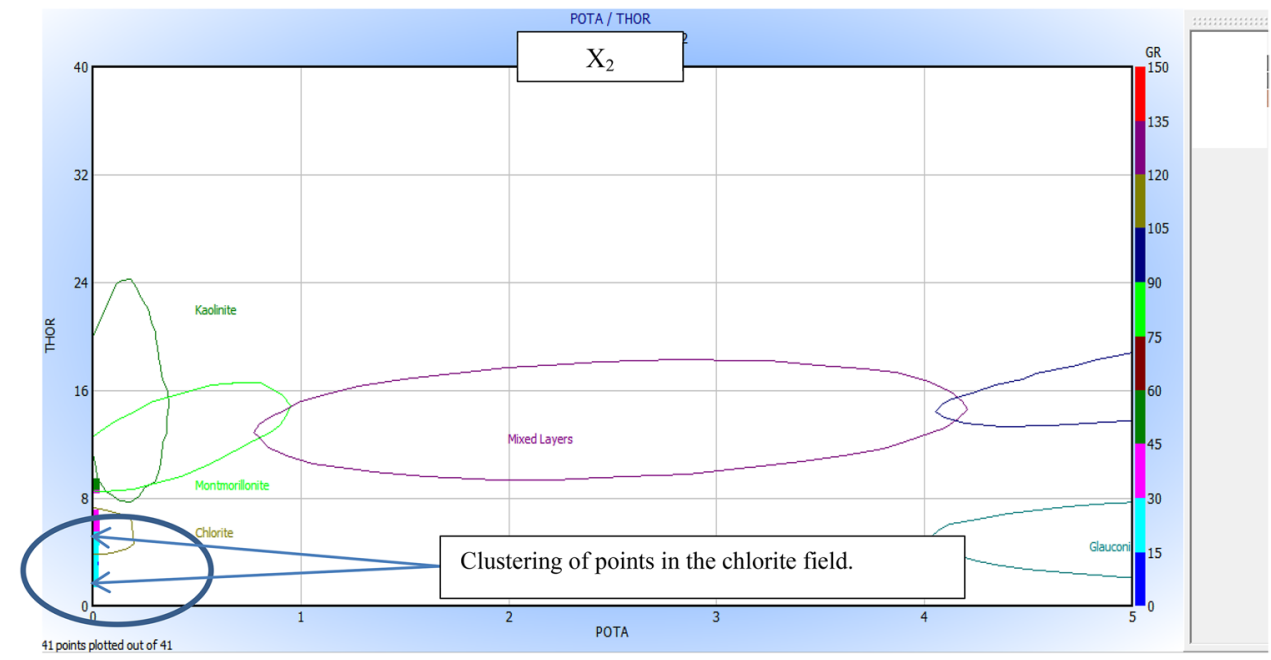

indicate that the reservoirs are heterogeneous comprising mainly of calcite-dolomite and subordinate quartz as matrix, and contain very little clay due to the high energy action that accompanied the formation of the channel sands leading to well-sorted reservoirs with good porosities. Chlorite occurs as the major clay mineral, and its formation is linked to primary deposition prior to sediment formation or to secondary diagenetic events that followed formation of the sediments; however, good porosities indicate that the clay mineral has a minimal effect on the reservoir quality. This research has shown that reservoir characterization studies using log motifs and petrophysical methods have enabled a better understanding of the reservoir architecture and features, depositional environment, reservoir quality, heterogeneities, and lateral extent of reservoirs occurring within the N'kapa Formation of the Doula Basin. This information should guide future exploration especially in siting new well locations within this N'kapa Formation.

Acknowledgements The authors acknowledge the African Union Commission (AUC) for providing funds to support this project and the Ministry of Mines, Industry and Technological Development (MINMIDT); and National Hydrocarbon Corporation (SNH), Yaoundé, Cameroon for providing research data.

Open Access This article is distributed under the terms of the Creative Commons Attribution 4.0 International License (http://creativeco mmons.org/licenses/by/4.0/), which permits unrestricted use, distribution, and reproduction in any medium, provided you give appropriate credit to the original author(s) and the source, provide a link to the Creative Commons license, and indicate if changes were made.

\section{References}

Allen JRL (1965) Late quaternary Niger Delta and adjacent areas: sedimentary environments and lithofacies. Am Assoc Pet Geol Bull 49:547-600
Allen JRL (1970) Sediments of the modern Niger Delta, a summary and review. In: Morgan JP, Shaver RH (eds) Deltaic sedimentation, modern and ancient, vol 15. SEPM Special Publication, Tulsa, pp 138-151

Asquith G, Gibson C (1982) Basic well log for geologists. American Association of Petroleum Geologist, Tulsa Methods in Exploration, Tulsa, p 216

Asquith G, Krygowski D (2004) Basic Well Log Analysis: AAPG Methods in Ex-ploration Series, p 16

Bloch S, Lander RH, Bonnell LM (2002) Anomalously high porosity and permeability in deeply buried sandstone reservoirs: origin and predictability. AAPG Bull 86:301-328

Brown A (1997) Porosity variation in carbonates as a function of depth. Mississippian Madison Group, Williston Basin, pp 29-46

Brownfield ME, Charpentier RR (2006) Geology and total petroleum systems of the West-Central Coastal Province (7203), West Africa: U.S. Geological Survey Bulletin 2207-B

Burke K, Dessauvagie TFJ, Whiteman A J (1971) Opening of the Gulf of Guinea and geological history of the Benue depression and Niger Delta. Nat Phys Sci 233(38):51

Chongwain GM, Osinowo OO, Ntamak-Nida MJ, Nkoa EN (2017) Seismic attribute analysis for reservoir description and characterization of M-Field, Douala Sub-Basin, Cameroon. Adv Petrol Explor Dev 15(1):1-10. https://doi.org/10.3968/10220

Curtis CD, Coleman ML (1986) Controls on the precipitation of early diagenetic calcite, dolomite and siderite concretions in complex depositional sequences. In: Gautier DL (ed) Roles of organic matter in sedimentary diagenesis, pp 23-35. (Special Publication No. 38. Society of Economic Paleontologists and Mineralogists, Tulsa. DL (ed), Roles of Organic Matter in Sedimentary Diagenesis, pp 23-25. Special Publication No 38. Society of Economic Paleontologists and Miner-alogists, Tulsa)

Emery D, Myers KJ (1996) Sequence stratigraphy. Black Ltd, Oxford

Folk RL (1959) Practical petrographic classification of limestones. AAPG Bull 43:1-38

Fertl WH, Vercellino WC (1978) Practicla log analysis. 4. Predict water cut from well logs. Oil Gas J 76(25):111-116

Goncalves CA, Harvey PK, Lovell MA (1995) Application of a multilayer neural network and statistical techniques in formation characterization. In: SPWLA 36th annual logging symposium, Paris, 26-29 June 1995, Society of Petrophysicists and Well Log Analysts, Houston, paper FF, pp 1-12

Heald MT, Larese RE (1974) Influence of coatings on quartz cementation. J Sediment Petrol 44:1269-1274 
Hilchie DW (1978) Applied openhole log interpretation. DW Hilchie. Inc., Golden

Hilchie DW (1990) Wireline: a history of the well logging and perforation business in the oil fields. D.W. Hilchie Inc., Boulder, pp 25-86

Irwin H, Curtis C, Coleman M (1977) Isotopie evidence for source of diagenetic carbonates formed during burial of organic-rich sediments. Nature 269:209-213

Johnston D (2004) Reservoir characterization improves stimulation, completion practices. Oil Gas J 102(4):60-63

Journel AG (1995) Geology and reservoir geology. Stochastic modeling and geostatistics. In: Yarus JM, Chambers RL (eds) AAPG computer applications in geology, Tulsa, pp 19-20

Kendall C (2003) Use of well logs for sequence stratigraphic interpretation of the subsurface. USC Sequence stratigraphy. University of South Carolina. http://strata.geol.sc.edu/index.html

Larionov VV (1969) Radiometry of boreholes. NEDRA, Moscow (in Russian)

Luzz-Arbouille T, Schmid E, Piperi T (2009) Recent discoveries offshore Douala Basin. Oral presentation at AAPG international conference and exhibition, Cape Town, South Africa, October, $26-29$

Manga CS (2008) Stratigraphy, structure and prospectivity of the southern onshore Douala Basin, Cameroon, Central Africa. Afr Geosci Rev 1:13-37

Morris RL, Biggs WP (1967) Using log-derived values of water saturation and porosity. In: PWLA 8th annual logging symposium, Denver, 12-14 June 1967

Mutti E, Ricci LF (1972) Turbidites of the Northern Apennines: introduction to facies analysis (English translation by T.H. Nilsen, 1978). Int Geol Rev 20:125-166

Ntamak-Nida MJ, Bourquin S, Makong JC, Baudin F, Mpesse JE, Ngouem CI, Komguem PB, Abolo GM (2010) Sedimentology and sequence stratigraphy from outcrops of the Kribi-Campo subbasin: lower Mundeck Formation (Lower Cretaceous, Southern Cameroon). J Afr Earth Sci 58:1-18

Osinowo OO, Ayorinde JO, Nwankwo CP, Ekeng OM, Taiwo OB (2017) Reservoir description and characterization of Eni field Offshore Niger Delta, southern Nigeria. J Petrol Explor Prod Technol. https://doi.org/10.1007/s13202-017-0402-7

Pauken RJ, Thompson JM, Schuman JR, Cooke JC (1991) Geology of the Douala Basin, offshore Cameroon. Am Assoc Petrol Geol Bull 75(3):651-652

Refae AT, Khalil S, Vincent B (2008) Increasing bandwidth for reservoir characterization with singlesensor seismic data: a case study from Libya's challenging Lehib field. Pet Afr 26(2):41-44
Rider M (1986) The geological interpretation of well logs. Blackie, Glasgow, pp 151-165

Rider MH (1996) Geological interpretation of well logs. French Consultant Ltd., Scotland

Schlumberger C (1977) Log interpretation/charts. Schlumberger Well Ser-vices Inc, Houston

Schlumberger (1989) Log interpretation charts. Schlumberger Educational Services

Schlumberger (1996) Log interpretation chart book. Schlumberger Well Surveying Corporation

Shanmugam G, Poffenberger M, Alava JT (2000) Tide-Dominated Estuarine Facies in the Hollin and Napo. AAPG Bull 84(5):652-682

Shanmugan G, Moiola RJ (1988) Submarine fans: characteristics, models, classification, and reservoir potential. Earth Sci Rev 24:383-428

Simon Petroleum Technology (SPT) (1994) Petroleum Geology and Hydrocarbon Potential of the Douala Basin, Cameroon Unpubl. Non-exclusive report

Simon Petroleum Technology (SPT) (1995) Petroleum Geology and Hydrocarbon Potential of the Douala Basin, Cameroon Unpubl. Non-exclusive report

Tamfu SF, Batupe M, Pauken RJ, Boatwright DC (1995) Geological setting, stratigraphy and hydrocarbon habitat of the Douala Basin, Cameroon. Am Assoc Petrol Geol Bull 79:13-95

Taylor TR, Stancliffe R, Macaulay CI, Hathon LA (2004) High temperature quartz cementation and the timing of hydrocarbon accumulation in the Jurassic Norphlet Sandstone, offshore Gulf of Mexico, USA. In: Cubit JM, England WA, Larter S (eds) Understanding petroleum reservoirs: towards an integrated reservoir engineering and geochemical approach, vol 237. Geological Society (London) Special Publication, London, pp 257-278

Uguru CI, Onyeagoro OU, Sikiru IO (2002) Permeability modelling for reservoirs in the Niger Delta based on geological descriptions and core data, SIPM Review Report, pp 4-98

Wyllie MRJ, Rose WD (1950) Some theoretical considerations related to the quantitative evaluation of the physical characteristics of reservoir rock from electrical log data. J Pet Technol 2(04):105-118

Publisher's Note Springer Nature remains neutral with regard to jurisdictional claims in published maps and institutional affiliations. 